\title{
The Perennial Philosophy in the Bhagavadgita: Where the East and the West Meet
}

\author{
Sabindra Raj Bhandari \\ http://dx.doi./org/10.4314/ujah.v22i1.6
}

\section{Abstract}

This article explores and interprets the fundamentals of perennial philosophy that the Bhagavadgita (the BG). The perennial philosophy of the BG crystalizes the first cause of reality. It leads to the zenith of knowledge, exhibiting how all the dualities and contradictions that run in this gross world merge into postulates the oneness of eternal reality. The eternity of the truth and first cause is in the integration and totality of oneness that radiates the entire creation. Western philosophy and science also make the same quest and disseminate the ideas and theories that resemble the perennial philosophy of the BG. In this regard, the entirety of perennial philosophy invites a systematic study. Having been compiled a few centuries before Christ, it remains to revisit how the BG resounds the rhythms of perennial philosophy propounded in the East and the West. This article has applied the qualitative approach. Exploratory and interpretive methods have been implemented to relate the ideas of perennial philosophy both from the BG and Western metaphysics.

Keywords: Atman, perennial philosophy, the Bhagavadgita, tat tvam asi, Vedanta)

\section{Introduction}

The Bhagavadgita (the $B G$ ) proclaims and postulates the concepts and dynamics of perennial philosophy. The $B G$ speculates the nature of absolute reality that drives the entire creation. This philosophy finds its 
perfect exemplifications and explanations in Western metaphysics, which also explains the primary cause of the entire phenomenal existence. The basic concepts of absolute reality and oneness find similar coincidences both in the East and the West. In this regard, it remains to explore the concepts of perennial philosophy in the $B G$ that make it a rendezvous for the philosophy of perennialism. This great book remains the epitome not only of the entire philosophy of Hindu scriptures but also provides insights into some great literary figures, philosophers, and scientists throughout the world. In its culmination, the $B G$ provides the summation of Vedanta, which is the philosophical part of Veda. The great Vedic Scholar Isherwood writes, "Vedanta is the philosophy of the Vedas, those Indian scriptures which are the most ancient religious writings now known to the world" (1). Thus, it invites a revisit and an exploration to find out how this philosophical book remains as the herald of the perennial philosophy. The popularity of this work is increasing because "by the 1980s, before the internet explosion there were estimated 3000 translations and nearly a thousand in English" (Pattanaik 27). From this standpoint too, it demands a fresh exploration as this creation of antiquity provides the ground for "the meeting of the orient and the occident" (Campbell v). In its underlying pattern, the $B G$ disperses the message for the whole of humanity.

The $B G$, also called the song of the Lord, contains seven hundred lofty verses which are embedded in the longest epic, the Mahabharata, written in the most powerful Sanskrit language. Its compiler was Vyasa. Scholars like Johnson guesses that this work belongs to "oral tradition that may have its origins in the eighth or ninth century BCE" (X). The poem is in a dramatic form where the chief speaker Shri Krishna, the Lord of the title, delivers the supreme secrecy of dharma (cosmic order), karma (action), jnana (knowledge), and bhakti (devotion) to a reluctant warrior-prince Arjuna, who is overcome by the despondency of morality that makes him hesitant to fight against 
his kiths and kins. The sonorous verses from this great book teach the essence of spiritual evolution with the insight of perennial philosophy, and so the great scientist Oppenheimer rightly calls this book "the most beautiful song existing in any known tongue" (qtd. in Goldberg 385). Thus, a fresh revisiting always proves to be justifiable to shine out the enigmatic philosophy that underlies in it.

\section{Review of Literature}

The $B G$ stands as a landmark in the arena of philosophical and religious thought in the world. It has always invited various adulations and felicitations. Its popularity is unsurpassable. The way it handles knowledge and truth has attracted scholars in the whole world to discuss its multi-dimensional aspects because it is such a book to "repeat and repeat" in the "important activities and trials of your day" (Doyle xi). Therefore, it has become a prime source of inspiration for many political and intellectual leaders throughout the whole world, and it always demands a new revisiting and interpretation.

The more one enters into the book, the more it mirrors the multiple facets of thoughts and hence is eternally fresh. Hiriyanna observes, "It is one of the hardest books to interpret, which accounts for the numerous commentaries on it - each differing from the rest in some essential point or other" (117). The BG attracts divergent interpretations now and again. Another cause of difference among the interpreters of the work is its unique but dramatic setting. It is delivered on a battlefield to a reluctant warrior, Arjuna, by his charioteer, Shri Krishna. A great enigma of philosophy was delivered in the hustle and bustle of war! In this aspect too, this study proves to be justifiable.

The $B G$ has been treated not only as a Vedanta Hindu scripture, but also a work of divinity with the appeal for universality because "the beauty and the power of the language in which this doctrine is inculcated, is unsurpassable, in any other work ..." ( Mac Donnell 409). 
The concept of perennialism always guides universalism, and it demands a deep exploration of how this great work popularizes this concept. Huxley rightly views the $B G$ as a beloved book that contains the fathomless ocean of knowledge. He defines it as the essence of all philosophy. He declares:

It is perfectly possible for people to remain good Christians, Hindus, Buddhists, or Moslems and yet to be united in full agreement on the basic doctrines of the Perennial Philosophy. The Bhagavad-Gita is perhaps the most systematic scriptural statement of the Perennial Philosophy. ("Introduction" 22)

The $B G$ is beyond the limitations of time, space and has become universal and eternal. In this regard, its message has a universal appeal. It is as fresh today as it was when delivered to Arjuna many centuries ago. Its value is so pervasive. So, a new revisiting to explore the doctrine of the perennial philosophy in this great classical work proves to be justifiable.

\section{Statement of Problem and Research Questions}

Researchers have explored various aspects of the $B G$. However, the concepts of perennial philosophy still invite a new exploration because the $B G$ projects that there is a single reality and the entire creation radiates out of it. The duality of this phenomenal world is just the play, and the entire antagonism merges in oneness beyond the mask of manifested reality. This reality is eternal. The essence of perennial philosophy underlies this principle. Western Metaphysics also makes more or similar speculations about the first cause or the absolute reality. To crystallize these concepts, this article answers the following research questions: What are the key ideas of perennial philosophy? How does the $B G$ postulate the ideas of perennialism that epitomizes it as a herald of perennial 
philosophy? Why do the philosophical concepts of the $B G$ find their great confluence in various ideas of perennialism projected by different philosophers and scientists from the West?

\section{Objectives}

The study aims to reveal how the fundamentals of perennial philosophy that the $B G$ postulates prove to be the milestone of perennialism in both the East and the West. It also intends to examine how the rhythms of philosophy heard in the $B G$ reverberate in the philosophical speculations of the West.

\section{Methodology}

The study follows the qualitative approach and applies the explorative and interpretive strategy to reveal the real essence of perennial philosophy in the $B G$. The qualitative approach explores, interprets, and perceives the meaning of any concept "inductively building from particulars to general themes" (Creswell 4). In this regard, to embark the perennial philosophy in the $B G$, this study interprets the verses from this holy book as the primary source of ideas. The verses from chapter II, which is a discourse on wisdom, have mainly been focused on. Likewise, the critical reviews, commentaries, and theories related to perennialism from various scholars and philosophers have been considered as the secondary sources to enhance the knowledge that this great work has dispersed both in the East and the West. The concept and essence of perennial philosophy have been applied as the theoretical lenses to explore the ideas and concepts that underlie this great work.

\section{The Perennial Philosophy, Its Basic Premises}

The perennial philosophy states that the eternal reality is omnipresent and absolute that dwells within all creatures and objects 
as everything is emanated from that source. This philosophy has a long tradition that could be traced almost three millennia. It bears some basic tenets which reverberate throughout the whole world. The great scholars Aldous Huxley and Joseph Campbell have beautifully provided the summation of this philosophy. In the great work, The Perennial Philosophy, Huxley writes:

PHILOSOPHIA PERENNIS - the phrase was coined by Leibniz, but the thing - the metaphysic that recognizes a divine Reality substantial to the world of things and lives and minds; the psychology that finds in the soul something similar to, or even identical with, divine Reality; the ethic that places man's end in the knowledge of the immanent and transcendent Ground of all living being - the thing is immemorial and universal. (1)

These concepts may prevail in almost every religion of the world. In its culmination, this philosophy proposes that you are the one with absolute reality as described by the ancient Upanishads that postulate Vedanta.

In Chandogya Upanishad, there is a powerful saying "tat tvam asi (Thou art that)" (Deussen 169), which embodies that you are the absolute reality. It signifies that the ultimate reality is within us. Similarly, Brihadaranyaka Upanishad also postulates "I am Brahman.' From it, all this came" (Muller 79), which also substantiates the concept that one is the ultimate reality, Brahman. It is not hasty to claim that these grand ideas become the foundation of the perennial philosophy. Again Huxley writes in The Perennial Philosophy, "A version of this Highest Common Factor in all preceding and subsequent theologies was first committed to writing more than twenty-five centuries ago and since that time the 
inexhaustible theme has been treated again and again, from the standpoint of a very religious tradition and in all the principal languages of Asia and Europe" (1). If he refers to twenty five centuries, it must be the Vedic philosophy. If the $B G$ hands down the summation of Vedanta, then it is certain that it is the paragon of the perennial philosophy.

In The Power of Myth with Joseph Campbell, a passage beautifully reveals the great confluence of perennial philosophy propagated in the Eastern Upanishads and the Holy Bible. The passage concludes: "The Christ is in you doesn't die. The Christ in you survives death and resurrects .... Heaven and hell are within us, and all gods are within us. This is the great realization of the Upanishads of India in the ninth century B.C. All the gods, all the heavens, all the worlds are within us" (qtd. in Goldberg 101). How beautifully the concepts from seemingly diverse religious thoughts play the same rhythm of the music. This idea of oneness is the essence of the Vedanta.

The Perennial philosophy has its voice that blows the totality of the whole school of thought. In the essay "The Minimum Working Hypothesis", Huxley provides the basic hypotheses of this philosophy:

That there is a Godhead, Ground, Brahman, Clear Light of the Void, which is the un-manifested principle of all manifestations. That the Ground is at once transcendent and immanent. That it is possible for human beings to love, know, and, from virtually, to become identical with the divine Ground.That to achieve this unitive knowledge of the Godhead is the end and purpose of human existence. That there is a law of Dharma which must be obeyed, a Tao or Way 
which must be followed if men are to achieve their end. (34)

These minimum working hypotheses lead a seeker from this gross world to the realm of infinite reality. This sublimation is the ultimate goal of the perennial philosophy. In the subsequent sections, it would be mesmerizing to find how the sonorous verses of the $B G$ make the perfect explanation and interpretations of the perennial philosophy where all the concepts of this philosophy meet.

\section{The Bhagavadgita: The Epitome of Perennial Philosophy}

The $B G$ opens the path for the realization of the Supreme Self, the ultimate reality that is really beyond the domain of one's reason and senses. The Western Metaphysics also speculates that humans cling to the pseudo-reality of this manifested world that hinders the realization of the Ground, Brahman, or the Clear Light of the Void which is the ultimate goal of perennial philosophy. In the $B G$, Shri Krishna, the chief speaker and the lord of the title, states the supreme truth at first in discourse II on Sankhyayoga (the yoga of pure wisdom). The interesting thing about the $B G$ is that it applies the teaching down method in which Shri Krishna expresses the main arguments and gist of the perennial philosophy in discourse two thinking that the wise one like Arjuna would understand the message, but the wavering mind of Arjuna could not grasp it. Then Shri Krishna leads to the elaboration of the basic essence of knowledge related to the essential truth of pure awareness known as jnana (perennial wisdom). The Lord gives a divine description that the Self as the ruler is not thought to be born or die. The imperishable transcendental one cannot be killed or destroyed. He states: 
The wise grieve not for those who live: and they grieve not for those who die - for life and death shall pass away. Because we all have been for all time: I, and thou, and those kings of men. And we all shall be for all time, we all forever and ever. As the Spirit of our mortal body wanders on in childhood, and youth and old age, the Spirit wanders on to a new body: of this, the sage has no doubts. (Mascaro 49)

Here, the $B G$ proposes the key presumption perennial philosophy. Shri Krishna makes the point that the Spirit, soul, atman, Ground, Brahman, or Clear Light of Void transcends the decay, and the living entities transform from one bodily stage to another. This is the cycle one has to be acknowledged. This is the fundamental essence of perennial philosophy that finds its essence in the voice of many philosophers from the western school of thought.

In our life too, we go on transformations from childhood to old age. The moment we consider our journey from birth to death, we face and see many phases of rebirth. The Greek philosopher Anaxagoras speaks the same essence of perennialism of the eternal Self or Spirit proposed by the $B G$ when he says, "something of everything" (qtd. in Gaarder 38). It has been a subject of a major quest for the scientists who believe that no level of energy can be created or destroyed; rather, the whole process is just the play, redistribution or transformation of energy or eternal consciousness, in term of the $B G$, from one form to another. This is the basic premise of the law of thermodynamics and the theory of energy conservation. The great scientist Einstein's equation of $E=\mathrm{mc}^{2}$ clarifies that nothing is destructible. It clarifies that "the amount of energy contained, in a particle's mass, $m$, times $c^{2}$, the square of the 
speed of light; thus E=mc ${ }^{2}$ " (Capra 223). Here "E" stands for energy, "c" for light, and "m' for mass. The lights move 300000 kilometers per second. In simple terms, if mass gets the speed of 300000 kilometers per second multiplied by 2 , then the mass is converted into energy and vice versa. To sate directly, " $\mathrm{E}=\mathrm{mc}^{2}$ simply means that mass can be thought as a kind of energy, and vice versa" (Hawking 30) or "The energy that belongs to the mass $m$ is equal to this mass, multiplied by the square of the enormous speed of light" (Einstein 340). Thus, nothing is perishable; rather there is the transformation of energy from one stage to another. In the above verses, the $B G$ expresses this genuine truth projecting the idea of perennialism even more than two and half millennia ago.

The Spirit (soul) is the primal energy that drives the entire manifestations. Likewise, we have different bodies within the same self even in this short span of life. This constant flux is reality. The $B G$, as an epitome of perennial philosophy, makes a quest for the realization of what we are in reality beyond appearance. These philosophical speculations reverberate in Parmenides when he says, "What men regard as real is the mere name" (qtd. in Srinivasan 10). There is only one reality, which Plato calls "the Idea - the only stable reality, that which underlies, motivates, and orders the flux of phenomena" (Tarnas 9). Time is transcended in the realm of this state of perenniality because the above verses from the $B G$ speculate there was never a time when we were not present, nor will be that in the future.

This concept of immortality and the oneness of Spirit finds its explanation in the atomic theory of Greek philosopher Democritus. His theory becomes the leitmotif of the perennial philosophy of the $B G$. Gaarder writes: 
Democritus believed that the soul was made up of special round, smooth "soul atoms." When a human being died, the soul atoms flew in all direction, and could then become part of a new soul formation ... . He agreed with Heraclitus that everything in nature "flowed," since forms come and go. But behind everything that flowed, some eternal and immutable things did not flow. (45)

The eternity of Spirit as the prime mover that the $B G$ postulates find its exemplification and better explanation being the concept of "soul atoms" in the philosophy of Democritus. It seems that he might have got acquainted with the perennial philosophy of that Shri Krishna projects in the $B G$.

There is something inert that differentiates living creatures from non-living beings. That is something non-physical, the life force, cosmic energy, Godhead, Ground, Light of the Void, or Tao. More than that it is referred to as the Atman (self /spirit) in the BG that is ever-present and eternal unlike the bodily matter as Plato talks about the "auto or Atman in describing his reading in reality" (qtd. in Srinivasan 10). Atman becomes atom! The BG postulates this enigma of perennial philosophy in these sonorous philosophical verses:

The unreal never is: The Real never is not. This truth indeed has been seen by those who can see the truth.

Interwoven in his creation, the Spirit is beyond destruction. No one can bring to an end the everlasting Spirit. For beyond time he dwells in these bodies, though these bodies have an end in their time; but he remains immeasurable, immortal. 
Bhandari: The Perennial Philosophy in the Bhagavadgita ...

Therefore, a great warrior, carry on the fight. (Mascaro 49-50).

What a magnanimous projection of perennial philosophy! Eternity is within us. We are all that absolute reality. The reality of "tat tvam asi" and "I am Brahman" discussed above find new interpretations here. Moses also proclaims the similar tones of eternity in The Holy Bible when he declares, "I AM WHAT I AM" (Exodus 3:14). This immortal energy always experiences the world with the help of the body. The body remains just like a musical instrument, and the cosmic energy which is consciousness is the player. Thus Rosen rightly claims that the $B G$ tells: "For the existent, there is no cessation, and for the non-existent-- like a dream or an illusion--there is no endurance" (9). Thus, being the cosmic consciousness, the spirit has no cessation. The body finds consciousness when the cosmic consciousness as Self dwells there. The Spirit as prime mover passes from one phenomenal body to another, making the whole cycle a flux and eternal that the $B G$ expresses above. So, Plotinus was right to say about the eternal reality because "while it is nowhere, nowhere is it not" (qtd, in Russell 273). We have to realize the voice of Jesus, "Here it is or there it is because the kingdom of God is within you" (Luke 17:20). Then the ultimate way is to "So watch yourselves" (Luke 17:3). This fundamental aspect of the perennial philosophy in the East and the West find their perfect blending in the $B G$. Shri Krishna's proclamation of this reality in the $B G$ is universal that resounds almost everywhere in the arenas of philosophical speculations.

\section{The Great Confluence}

The $B G$ remains the milestone of perennial philosophy. The above discussion has stated that the eternal self transcends the physical manifestations of this world of becoming. The eternity of Self 
always radiates this world of becoming. These speculations of Shri Krishna's perennial philosophy resound in Kant's philosophy when he says, "The universe is only appearance and not the reality (ding an sich or appearance, not the thing in itself)" (qtd. in Srinivasan 10). It is only the pure Self (Atman) that is not embroiled in the mortal world. It transcends the time and space dimension and can integrate the humans into the abode of the real Self (Brahman). Shri Krishna brings that integration when he says, "In this whole vast universe there is nothing higher than I. All the worlds have their rest in me, as many pearls upon a string" (Mascaro 74). That's because the real Self is imperishable and is beyond decay. This perception is found in Walt Whitman's "Passage to India" where he writes about "the actual me" and the phrase "like the real me" and "I pass death with the dying" (qtd. in Rosen 152). This agrees with the concept of soul, its immortality, and transitoriness of gross body that Shri Krishna projects in the $B G$. The cosmic Self is never destroyed; rather it is forever.

The perennial philosophy projects for the perfect way and eternal realization. The lower self produces ego and personality, which may dissolve. The real self, being the ruler, is always there. No death, no real change, no real transition is there for the Self. The real is the Self. The real Self "is changeless (nitya), all-pervading (sarvagata), stable (sthanu), unshakable (acala), and permanent (sanatana)" (Zimmer 385). Thus, the real owner is always transcendent; just the body is subject to decay. Lamentation for the perishable of worldly affairs does not suit a great warrior like Arjuna. Shelly, the great poet, might have got acquainted with this great philosophy of perenniality and writes in "Adoinas," "The One remains, the many change and pass" (qtd. in Goldberg 270). This universality of perennialism disseminated by the $B G$ recurs as the 
leitmotif in the religious, literary, and philosophical traditions of Asia and Europe.

The real seer does not grieve for the things that need the grievance because the real seer detects transitoriness from the eternal. One who sees the real never worries about the decay of gross reality. Genuine knowledge and the stage of perenniality bring spiritual evolution. Then one is capable of remaining aloof from the changes that sensory perceptions give. This sense of rapprochement between the antagonistic theses are merged in the stage of transcendence as the $B G$ states, "For he whom these do not disturb and to whom pain and pleasure are alike, that steadfast man, $\mathrm{O}$ prince of men, is fit for deathlessness" (Hill 85). The transcendental and perennial stage is that when two diverse poles are synthesized. In this stage, death and life become one.

The extreme antagonistic polarities are transcended by the jnani (the man of pure wisdom), knowing that these phenomenal manifestations are simply the shadowy play of the self which is transcendental. The shadows come and go, in the same way, these bodily manifestations like the shadows, only flicker, not the real self. The $B G$ states:

If any man thinks he slays, and if another thinks he is slain, neither knows the ways of truth. The Eternal in man cannot kill: the Eternal in man cannot die.

He is never born, and he never dies. He is in Eternity: he is forevermore. Never-born and eternal, beyond times gone or to come, he does not die when the body dies. (Mascaro 50)

The philosophical lines from the $B G$ proclaim perenniality - the stage of transcendence - when the situation of deathlessness emerges. It is something which death cannot decay 
for that lies within us because eternity is within us. The point is that if the Self is unborn, therefore it is beyond death. It is only in this stage of discontinuity that one can have communion with that unborn reality. So, as Tagore confirms, "Man is immortal, therefore he must die endlessly" (qtd. in Mehta 20), and then "one knows death while living. Only in that dying, in that coming to an end, putting an end to continuity, is their renewal, that creation which is eternal" (Krishnamurti 23). Here, one has to note that the sense of continuity is not immortality because continuity has come to a discontinuity at some point. In the above verses, Lord Krishna means to say that when the sense of continuity ends, then dawns immortality.

The $B G$ transcends death and time. This is the crux of perennial philosophy. In the $B G$, "death is an impossibility. Nobody has ever died; nobody can ever die. Death is a deception" (Osho 233). Only the paragon of perennial philosophy can proclaim about that stage. Death remains a mere illusion when Shri Krishna clarifies with a rhetorical question: "He who knows that it is indestructible and eternal, uncreated and unchanging, how can such a person slay anyone, O Partha (Arjuna), or cause anyone to slay?" (Radhakrishnan 122)). Shri Krishna propagates this perennial knowledge that if the Self is not for decay, it is not worthy to grieve for it. And if the body is not permanent, is it rational to grieve about it? Either way, the conclusion is reached. The real is the One, what goes here are mere manifestations. These wonderful dialogues between Crito and Socrates crystallize this point: "When Crito asks, 'In what ways shall we bury you, Socrates?' Socrates answers, 'In any way you like, but first, you must catch $m e$, the real me. Be good of cheer, my dear Crito, and say that you are burying my body only, and do with that whatever is usual and what you think best."' (qtd. in Radhakrishnan 123). Reality is tat tvam asi (You are that). This 
basic Oneness of infinity is the culmination of the perennial philosophy. This is the reality that Shri Krishna is propagating as Leibniz says, "there is nothing waste, nothing sterile, nothing dead in the universe" (qtd. in Cottingham 3). Everything is eternal. This is the fundamental message of the $B G$.

One who knows this secret of perenniality knows all. The Occident also believes that true knowledge arises out of the relation between the Self and not-Self. The Philosophy of Hegel in its culmination also reveals the concept that the real is a synthesis of two antagonistic polarities of thesis and antithesis. The real harmonious reconciliation between them is the perennial process. Karl Marx's philosophy infers the dialectic process as a perpetual one. If so, Shri Krishna is right to say, "O Arjuna, be beyond duality, ever established in the highest reality, free from thoughts of possessions and comfort" (Marjonovic 45). Arjuna's despondency just sees the one-sided polarity of death, discarding the totality of another side. He simply moves around the reality that is manifested. Reality dawns when he transcends the stage of relativity.

Arjuna does not understand this reality because he only sees the polarity of the immortal as a mortal. To visualize the true reality of mortals as immortals, Lord Krishna unfolds the whole mystery of true knowledge of perenniality (Shankhyal jnana). He postulates the crux of perennially:

Swords cut him not,

Fire burns him not,

Water wets him not,

Wind dries him not.

Not to be cut is he, not to be burnt is he,

Not to be wet not yet dried;

Eternal, omnipresent, fixed,

Immovable, everlasting is he 
Unmanifest he, unthinkable he,

Unchangeable he is declared to be;

Therefore knowing him thus

Thou shouldst not mourn him. (Edgerton 19)

The reality is the One. Everything that is manifested is the immanence of that transcendental One. Reality transcends change, time, space, and even death. What a positive philosophy of perennialism! That's why, the evolution of wisdom dawns when the manifest entities realize the all in the One, and the One in the all. Then an individual, as Shri Krishna clarifies, can see his immortal Self, the Brahman, Ground, Clear Light of Void beyond the law of causation.

\section{Conclusion}

The $B G$ affirms the fundamental assumptions of perennialism. It projects that the Self as the first cause radiates the entire creation. All dwells in it and vice versa. Thus, in essence, everyone is eternal. The grand ideation of tat tvam asi, which signifies that the ultimate reality is within us, has been fully developed and justified in this great work. Being the landmark of the perennial philosophy, it postulates that the worldly phenomenal manifestations are only the subject to change and decay, but the Self that drives the entirety, dwelling within us as the prime mover, is eternal. Forms go on transformations, but not the essence. These fundamentals of perenniality find their better exemplification in the theory of conservation of energy, and the law of thermodynamics of modern science. Likewise, the idea of Oneness as the first cause of creation has become the point of confluence between the theories and philosophies propounded in the East and the West. Democritus' theory of atomic soul resembles the idea of Atman (Self/ soul) of the 
$B G$. The concepts of Socrates real me; Plato's Ideas; Anaxagoras' Everything; Plotinus' One; Kant's thing-in-itself resound the perennial philosophy of the $B G$. All these philosophical proclamations remain as the metamorphoses of the concept of Atman as the cosmic creation that the $B G$ postulates in the lofty verses. One is mesmerized to hear the similar echoes of perenniality in Moses and Christ. The BG projects that the first cause, summum bonum, is an integrated totality. The idea is the fundamental exponent of western philosophy. The $B G$ also projects that the dualities and antagonisms go only in this phenomenal world, but in the realm of oneness, they all merge. Similarly, the philosophy of Hegel and Marx proposes that the harmonious assimilation of two antagonistic polarities is the essence of reality, and this process goes perpetually. Likewise, the $B G$ proclaims that the stage of perenniality is to perceive the dualities and opposites so that one can embrace the whole. The moment one attains this evolution within, the distinction between life and death, joys and sorrows, and the polarities vanish. In essence, they all are one. That's why the $B G$ makes the ideation that there is no death. What a philosophy! Everything is immortal. Thus, to renounce one for another is to deny the supreme reality. This is the crux of perennial philosophy that the $B G$ postulates where the entire tenets of this philosophy propounded in the East and the West find their perfect blending. This great work is so fresh that it always invites and awaits further exploration in the days ahead, and enchants the knowledge and wisdom forever.

Sabindra Raj Bhandari, PhD Asst. Prof., Department of English, Prithvi Narayan Campus, Tribhuvan University, Nepal. bhandarisabindra@gmail.com 



\section{Works Cited}

Campbell, Joseph. Foreword. Philosophies of India, by Heinrich

Zimmer, Motilal Banarsidass, 2011, pp. V-VII.

Capra, Fritzof. The Tao of Physics. Flamingo, 1991.

Cottingham, John. On the Meaning of Life, Thinking in Action.

Taylor and Francis Group, 2003.

Creswell, John. W. Research Design. Sage, 2011.

Deussen, Paul. Sixty Upanisads of the Vedas. Translated by V.W.

Bedekar and G.B. Palsule. 2 vols. Motilal Banarsidass, 2010.

Doyle, Richard. Foreword. Dancing Beyond Thought, Bhagavad Gita's Verses and Dialogues on Awakening, by Gary Weber, Create Space Independent Publishing, 2013, pp. xixii.

Edgerton, Franklin, editor, and translator. The Bhagavad Gita. Motilal Banarsidass, 1994.

Einstein, Albert. Ideas and Opinions. Edited by Carl Seeling, Rupa, 1999.

Gaarder, Jostein. Sophie's World. Translated by Paulette Moller, Berkeley Books, 1996.

Goldberg, Philip. American Veda. Three Rivers P, 2010.

Hawking, Stephen. Brief Answers to the Big Questions. John Murray, 2018.

Hill, W. D. P., translator. The Bhagavadgita. OUP, 2007.

Hiriyanna, M. Outlines of Indian Philosophy. Motilal Banarsidass, 2000.

Huxley, Aldous. Introduction. The Song of God: Bhagavad-Gita, by Prabhavananda and Isherwood, Mentor Book, 1972, pp. 11-22. 
---. "The Minimum Working Hypothesis". Vedanta for the Western

World, edited by Christopher Isherwood, George Allen and Unwin Ltd., 1949, pp. 33-35. www.pdfdrive.com. Accessed 5 May 2021.

---. The Perennial Philosophy. Chatto and Windus, 1947. www.pdfdrive.com. Accessed 7 July 2020.

Isherwood, Christopher, editor. Vedanta for the Western World. George Allen and Unwin, 1949. www.pdfdrive.com. Accessed 9 March 2021.

Johnson, W. J., translator. The Bhagavad Gita. Oxford UP, 2008.

Krishnamurti, J. The First and the Last Freedom. Krishnamurti Foundation India, 1992.

Mac Donnel, Arthur. A History of Sanskrit Literature. Munshiram Manoharilal, 1972.

Marjonovic, Boris, translator. Abhinava Gupta's Commentary on the Bhagavad Gita: Gitartha Samgraha, by Abhinava Gupta, Indica Books, 2004.

Mascaro, Juan, translator. The Bhagavadgita. Penguin Classics, 1994.

Mehta, Rohit. From Mind to Super-Mind. Motilal Banarsidas, 2006.

Muller, F. Max, translator. Upanishads. Wordsworth Classics, 2000.

Osho. Gita Darshan, Discourses on Yoga of Sorrow and Yoga of Knowledge, Full Circle, 2012.

Pattanaik, Devdutt. My Gita. Rupa Publication, 2015.

Radhakrishnan, S., editor and translator. The Bhagavadgita. Harper Collins Publishers, 2010.

Rosen, Steven J. Krishna's Song: A New Look at the Bhagavadgita. Praeger, 2007. 
Russell, Bertrand. History of Western Philosophy, Routledge Classics, 2013.

Srinivasan, Ramkrishnan. Vedic Tradition and World Religions. Sri Sri Publications Trust, 2016.

Tarnas, Richard. Passion of the Western Mind. Pimlico, 2000.

The Holy Bible. International Bible Society, 1984.

Zimmer, Heinrich. Philosophies of India. Translated by Joseph Campbell, Motilal Banarsidass, 2011. 